\title{
Length of Stay and Outcome of Hospitalized Chronic Obstructive Pulmonary Disease Patients, Differences between General Medical Ward and Intensive Care Unit: A Cohort Study
}

\author{
N Makhoul ${ }^{1}$, R Khamisy-Farah², R Farah ${ }^{3}$
}

\begin{abstract}
Background: Exacerbations of Chronic Obstructive Pulmonary Disease (ECOPD) are a major problem worldwide and usually a leading cause for hospitalizations and in some cases, indication for invasive mechanical ventilation (IMV).

Objective: The aim of this study was to determine the length of stay in hospital and outcome of ECOPD patients. We compared the length of hospital stay in the medical ward, intensive care unit (ICU) departments and discharges during a period of six months.

Methods: This was an observational, longitudinal prospective study of 242 COPD patients that were admitted with COPD exacerbation. In each patient, acute physiology and chronic health evaluation (APACHE) II score and serial arterial blood gases $(A B G)$ were measured upon and during admission. Results: Eighty per cent (194) of 242 COPD patients were admitted to the medical department and most of them were discharged within five days. Forty-eight needed IMV and stayed in hospital more than ten days; overall mortality rate was about $5 \%$.

Conclusion: Most of the hospitalized patients with COPD exacerbation (60\%) were discharged within five days, 20\% needed IMV and stayed in hospital more than ten days.
\end{abstract}

Keywords: Chronic obstructive pulmonary disease (COPD), hospital stays, mechanical ventilation, non-invasive mechanical ventilation

\section{Duración de la Estancia y Resultado de los Pacientes Hospitalizados por la Enfermedad Pulmonar Obstructiva Crónica. Diferencias entre la Sala Médica General y la Unidad de Cuidados Intensivos: Un Estudio de Cohortes}

N Makhoul ${ }^{1}$, R Khamisy-Farah², R Farah ${ }^{3}$

\begin{abstract}
RESUMEN
Antecedentes: Las exacerbaciones de la enfermedad pulmonar obstructiva crónica (EPOC) representan un problema grave en todo el mundo, constituyen generalmente una de las causas principales de las hospitalizaciones, y son en algunos casos la indicación de que se requiere ventilación mecánica invasiva (VMI).

Objetivo: El objetivo de este estudio fue determinar la duración de la estancia en el hospital y el resultado de los pacientes de EPOC. Comparamos la duración de la estancia hospitalaria en la sala médica, las unidades de cuidados intensivos (UCI), y las altas producidas en un periodo de seis meses. Métodos: Se trata de un estudio prospectivo, observacional, y longitudinal de 242 pacientes con EPOC que fueron ingresados con exacerbación de la EPOC. A cada paciente se le hicieron mediciones mediante la puntuación de la escala de Evaluación de la fisiología aguda y salud crónica (APACHE II) y la gasometría arterial seriada, tanto al momento de ingresar como durante el ingreso.
\end{abstract}

From: ${ }^{1}$ Intensive Care Unit, Western Galilee Hospital, Nahariya, Israel, ${ }^{2}$ Clalit Health Service, Western Galilee, Israel and ${ }^{3}$ Department of Internal Medicine B, Ziv Medical Center, Faculty of Medicine in the Galilee, BarIlan University, Safed, Israel.
Correspondence: Dr R Farah, Department of Internal Medicine B, Ziv Medical Center, POB 21, Safed 13100, Israel. E-mail: Raymond.F@ziv.health.gov.il 
Resultados: El ochenta por ciento (194) de los pacientes 242 pacientes con EPOC, fueron ingresados en el departamento médico, y la mayoría de ellos fueron dados de alta en cinco días. Cuarenta y ocho necesitaron VMI, y permanecieron en el hospital más de diez días. La tasa de mortalidad general fue alrededor del $5 \%$.

Conclusión: La mayoría de los pacientes hospitalizados con exacerbación de la EPOC (60\%) fueron dados de alta dentro de cinco días. El 20\% necesitó VMI, y se permaneció en el hospital más de diez días.

Palabras claves: Enfermedad pulmonar obstructiva crónica (EPOC), hospitalizaciones, ventilación mecánica, ventilación mecánica no invasiva

West Indian Med J 2013; 62 (8): 739

\section{INTRODUCTION}

The prevalence of chronic obstructive pulmonary disease (COPD) is progressively increasing in industrialized countries due to ageing populations (1). Furthermore, chronic comorbidities often coexist in the elderly population, enhancing the risk of functional decline and influencing the patient's management and outcome (2). Acute exacerbation of COPD (AECOPD) is a common cause of hospitalization, and the readmission rate is high, with more frequent exacerbations occurring in those with the most severe disease. According to the clinical situation and biochemical parameters, most patients should be admitted in general medical wards (GMW) and severe patients, especially who need mechanical ventilation, should be hospitalized in the intensive care unit (ICU). On average, 5-15\% of adults in industrialized countries have COPD defined by spirometry (3-6). Chronic obstructive pulmonary disease is now the $4^{\text {th }}$ leading cause of death worldwide; its mortality is rising, while cardiovascular disease's is falling; COPD is expected to be the $3^{\text {rd }}$ leading cause of death in the next 20 years (3). A new study showed a decrease in incidence of hospital admission of AECOPD with concomitant reduction in hospital mortality, despite increasing co-morbidity during the admission period, with no variations in length of hospital stay (7).

After diagnosis, the 10-year survival rate is approximately $50 \%$ with more than one-third of patients dying due to respiratory insufficiency (5). The aetiology of COPD is overwhelmingly dominated by smoking, although many other factors can play a role. Particular genetic variants are likely to increase the susceptibility to environmental factors, however, little is known about the relevant genes. Although there is accumulating evidence that oxygen therapy, pharmacological treatment and rehabilitation may the course of COPD, abstaining from smoking continues to be the most relevant measure, not only in preventing COPD, but also in arresting its development $(8-10)$.

The aim of this study was to define the outcome of hospitalized patients with AECOPD, examining the differences between the various departments.

\section{SUBJECTS AND METHODS}

This prospective, observational study was conducted in the medical, general intensive care and respiratory intensive care departments in the Nahariya Hospital during six months. During October 2008 to April 2009, 242 patients known to have COPD according to spirometric confirmation (FEV1/FVC of less than 0.7) with no response to bronchodilators, and current or past smoking history $>20$ pack/ years, on long term oxygen therapy (LTOT) presented with COPD exacerbation. The study was approved by the institutional committee in accordance with the Helsinki Declaration.

Both women and men over the age of 30 years who were hospitalized with worsening COPD were examined during the six-month period in the departments of intensive care and internal medicine. The following data were collected for all selected patients who meet the criteria of AECOPD: full blood tests including blood gases, demographic data, ventilation need during the period of hospitalization and the relationship between the indices for hospitalization and ventilator time.

\section{Study protocol}

Age, gender, smoking history, co-morbidity, LTOT forced spirometric parameters and arterial blood gas data were collected. Co-morbidity was quantified according to the Charlson co-morbidity index (11). Patients were selected from the emergency room during the acute exacerbation.

\section{Inclusion criteria}

* Patients over 30 years of age.

* Patients with COPD. A patient was classified as having COPD if he/she was chronically treated with inhaled oral bronchodilators or inhaled steroids or both over the two years preceding the admission with or without recurrent hospitalization for any COPD-related conditions, and had airway obstruction defined as FEV1/FVC of less than 0.7. Clinical evaluation and pulmonary function testing prior to admission showed airflow obstruction of 
FEV1/FVC $<70$ with a change in FEV1 of less than $200 \mathrm{ml}$ and $12 \%$ in the bronchodilators. The severity of the disease was established according to the latest Global Initiative on Obstructive Lung Disease (GOLD) criteria $(5,6)$.

* Patients with worsening disease: shortness of breath, cough, sputum emissions, ambulatory treatment failure.

Patients with AECOPD without respiratory distress and $\mathrm{pH}>7.30$ and needing only non-invasive mechanical ventilation (NIVMV) were admitted to the general medical ward.

\section{Indication for invasive mechanical ventilation and admission to ICU}

* Severe dyspnoea with use of accessory muscles and paradoxical abdominal motion.

* Respiratory rate was $>35$ breaths/minute.

* Life-threatening hypoxaemia $\left(\mathrm{PaO}_{2}, 5.3 \mathrm{kPa}, 40\right.$ $\mathrm{mmHg}$ or $\mathrm{PaO}_{2} / \mathrm{FIO} 2,200 \mathrm{mmHg}$ ).

* Severe acidosis $(\mathrm{pH}, 7.25)$ and hypercapnia $\left(\mathrm{PaCO}_{2}\right.$, $8.0 \mathrm{kPa}, 60 \mathrm{mmHg})$.

* Respiratory arrest.

* Somnolence, impaired mental status.

* Cardiovascular complications (hypotension, shock, heart failure).

* Other complications (metabolic abnormalities, sepsis, pneumonia, pulmonary embolism, barotrauma, massive pleural effusion).

* Non-invasive positive pressure ventilation (NIPPV) failure (or exclusion criteria).

\section{Exclusion criteria}

* Patients with sepsis or other infection on admission.

* Patients with pulmonary oedema or acute left heart failure defined by clinical criteria, history, chest Xray and bed side echocardiography.

* Patients with end stage kidney disease and on dialysis, and severe liver disease.

* Patients with AIDS, other immunosuppressive patients or those with severe malignancy.
* Patients with acute cerebrovascular disease.

The study was performed after each patient signed an informed consent form for blood sampling and data analysis and was approved by the institutional committee in accordance with the Helsinki Declaration and the Institutional Review Board.

\section{Statistical analysis}

Qualitative data such as co-morbidities, demographics, disease severity and mortality are described using frequencies and percentages. Quantitative data (duration of hospitalization in the unit and the departments, the values of laboratory data, etc) are described by mean and standard deviations, median, minimum and maximum, like $t$-test by matches. Statistical analysis was performed using the SPSS11 programme. Data are expressed as means \pm SD. Differences in mean values were tested by two-way analysis of variance (ANOVA) with adjustment for multiple comparisons (Bonferroni's test), using Prism version 3.0 statistical software (GraphPad software, San Diego, California, USA). Correlations between different study parameters were performed alone using Pearson correlation coefficients; $p<$ 0.05 was considered significant.

\section{RESULTS}

Two hundred and forty-two patients were enrolled in this study. All of them had COPD and were admitted to hospital due to worsening of COPD. The majority, 186, were men $(77 \%) ; 56$ were women $(23 \%)$ and the ages ranged from 34 to 97 years (67 years average). Most of the subjects smoked or smoked in the past, about half of the patients suffered from hypertension, one-third had diabetes and 20\% were obese, $60 \%$ on LTOT.

Most patients, 194 (80\%), were admitted to the internal medicine department and 48 patients (20\%) needed respiratory support and were transferred to the ICU. For each patient, the acute physiology and chronic health evaluation (APACHE) score was calculated where the most ventilated patients had higher APACHE scores, averaging 24 points (Tables 1, 2).

Table 1: Total days in hospital, differences between various departments

\begin{tabular}{lcccc}
\hline Total & Exacerbation & Number of patients & Mean days & Std deviation \\
\hline Medical department & $\begin{array}{c}\text { No mechanical } \\
\text { ventilation } \\
\text { Invasive mechanical } \\
\text { ventilation }\end{array}$ & 194 & 4.58 & 3.3 \\
$\begin{array}{l}\text { Intensive care unit (ICU) } \\
\text { department }\end{array}$ & 48 & 5.85 & 6.0 \\
& $\begin{array}{c}\text { No mechanical } \\
\text { ventilation } \\
\text { Invasive mechanical } \\
\text { ventilation }\end{array}$ & 194 & 4.58 & 3.3 \\
Total days in hospital & 48 & 11.29 & 9.8 \\
\hline
\end{tabular}

Independent sample $t$-test 
Table 2: Correlation between APACHE II score, age and invasive mechanical ventilation

\begin{tabular}{|c|c|c|c|c|c|c|}
\hline & $\begin{array}{c}\text { Exacerbation of } \\
\text { COPD }\end{array}$ & $\mathbf{n}$ & Mean & Std deviation & Range & $p^{*}$ \\
\hline \multirow{2}{*}{ Age } & $\begin{array}{l}\text { Invasive mechanical } \\
\text { ventilation }\end{array}$ & 48 & 67.9 & 13.48 & $34-95$ & $\begin{array}{c}0.471 \\
\text { two-sided }\end{array}$ \\
\hline & $\begin{array}{l}\text { No mechanical } \\
\text { ventilation }\end{array}$ & 194 & 66.46 & 11.77 & $36-96$ & \\
\hline \multirow{2}{*}{$\begin{array}{l}\text { APACHE II } \\
\text { score }\end{array}$} & $\begin{array}{l}\text { Invasive mechanical } \\
\text { ventilation }\end{array}$ & 48 & 24.04 & 7.38 & $7-39$ & $\begin{array}{c}p<0.001 \\
\text { two-sided and } \\
\text { one-sided }\end{array}$ \\
\hline & $\begin{array}{l}\text { No mechanical } \\
\text { ventilation }\end{array}$ & 194 & 15.79 & 4.31 & $6-31$ & \\
\hline
\end{tabular}

Among patients admitted to internal medicine, the condition of $60 \%$ improved rapidly and they were discharged within five days. The average days of hospitalization of all patients who were in the department of internal medicine were $4.6 \pm 3.3$.

In contrast, patients that required respiratory support and were admitted to the ICU stayed twice as long: 10 days of hospitalization. The average number of hospitalization days in the ICU department was between two and four days and a small number needed prolonged hospitalization up to 39 days. In this group with prolonged hospitalization, there were high percentages of various complications, especially recurrent infections and worsening of chronic compensated right heart failure.

Twelve hospitalized patients $(5 \%)$ died in the ICU; most of these patients were older than the average age of 77 years, with other chronic diseases (Table 3).

Table 3: Correlation between age of patients and mortality

\begin{tabular}{lrccc}
\hline Dead/Alive & $\mathbf{n}$ & $\begin{array}{c}\text { Mean age } \\
\text { (years) }\end{array}$ & Std deviation & $\begin{array}{c}\boldsymbol{p} \\
\text { two-sided } \\
\text { one-sided }\end{array}$ \\
\hline Alive & 230 & 66.23 & 12.127 & $\begin{array}{c}0.001 \\
\text { Dead }\end{array}$ \\
\hline
\end{tabular}

The average score on the Charlson index was 3.0 (2.5). The most commonly observed co-morbidities in this index were hypertension $(50 \%)$, diabetes $(30 \%)$, obesity with dyslipidaemia (18\%) and 2\% with compensated heart failure.

Regarding ambulatory treatment prior to current admission, $80 \%$ of the patients received long-acting beta agonists (LABAs) and 60\%, LTOT; the others received inhaled corticosteroids, antimuscarinics and other drugs not related to COPD as statins, anti-platelet drugs, diuretics and angiotensin-converting enzyme inhibitors or angiotensin receptor blockers.
The relation between the need for mechanical ventilation (MV) and age, gender or APACHE score: In order to assess the severity of the disease, APACHE score was calculated at admission for each of the 242 patients; they received an average APACHE score of 18. The higher the APACHE score, the worse the prognosis. While no correlation was found between age or gender and the need for $\mathrm{MV}$, a strong correlation was found between the calculated APACHE score and the need for MV (Table 2).

Relationship between disease severity and length of hospitalization: The need for MV usually causes prolongation of admission days, two days more on average, compared to non-ventilated patients.

\section{DISCUSSION}

In this prospective, observational study, we tested 242 patients who were admitted in the department of internal medicine, general and respiratory intensive care units for ECOPD, during a six-month period. Exacerbation of chronic obstructive pulmonary disease is defined as worsening of a patient's baseline symptoms such as dyspnoea, cough and/or sputum production that can induce a significant decrease in daily functioning levels (1). Knowing these signs can also reduce the life-threatening risks from a sudden flare of COPD associated with the development of respiratory failure, presence of chronic diseases and need for IMV (12, 13). We have also examined the course of the disease, improvement in dyspnoea, need for invasive ventilation during the hospital stay, duration of IMV, length of hospitalization in various departments including intensive care unit, in addition to examining mortality rates and prognosis. For each patient, we calculated APACHE II score rating and followed clinical and laboratory parameters during their admission.

There are many risk factors for COPD exacerbation that go beyond FEV1 decline and reflect the systemic nature 
of the disease. Key factors associated with increased risk for COPD exacerbation are identified as upper or lower respiratory tract infection, previous hospitalization due to COPD, old age, continued smoking, chronic mucous hypersecretion, significant co-morbidity and poor exercise capacity. Pulmonary hypertension, hypoxia, hypercapnia, poor health status and lack of patient awareness of the illness are also recognized as risk factors (14-16).

Over $70 \%$ of patients in our group were men; it remains unclear whether there is a link between gender and the development of COPD.

Several studies indicate that this disease is more common among men and thus their higher mortality rate, but recent significant increases in the percentage of women who smoke may show that women are more susceptible to the influence of smoking than men $(16,17)$. Most patients in this group were smokers or former smokers.

Smoking is highly correlated with the risk of developing COPD (17). The age of our patients ranged from 34 to 97 years, average 67 years. We know that morbidity in COPD increases with age and more so in men. Several studies demonstrated lower mortality rates among patients younger than 45 years old and also found that this disease is $4^{\text {th }}$ or $5^{\text {th }}$ among causes of death at ages above 45 years (17).

From this group of subjects, $80 \%$ of the patients were admitted to the internal medicine department and about $20 \%$ of these cases were more serious and needed IMV. Most patients $(60.7 \%)$ required hospitalization for less than five days, one-third of the patients were hospitalized between five and 14 days, 3\% were hospitalized for 15-21 days and another $3 \%$ hospitalized for more than three weeks. In this study, we found a clear relationship between the severity of the disease and the number of hospitalization days $(p<$ $0.001)$.

Various studies examined the number of hospitalization days of patients with COPD exacerbation to be more than five days. Patients with prolonged hospitalizations had a high percentage of complications such as infections, failure to wean from IMV and worsening right heart failure. About $20 \%$ of the patients in our group needed IMV and were hospitalized in the intensive care unit; in this group, mortality rate was higher $(11,18-22)$. Indications for IMV in our study were similar to those described in the literature, respiratory failure, by clinical or laboratory data.

Patients needed IMV defined by parameters specified in the world literature: $\operatorname{GOLD}(5,6)$. All patients in the group of IMV had respiratory acidosis with significant carbon dioxide retention and they all had a high APACHE II score. According to the data found in this study, most patients requiring IMV had APACHE II score around 24 points. As described in the literature, there is a clear relationship between high APACHE II score on admission and the need for IMV $[p<0.001]$ (Table 2). Average duration of IMV in our study was $20 \%$ lower than that described in the literature, 2-4 days. T-tube and low-level pressure support was per- formed to obtain premature extubation. As in our patients, a clear difference was found between disease severity, length of stay in the intensive care and internal medicine departments $(p<0.001)$. Also a high relation between the severity of the disease and length of IMV was found $[p<0.001]$ (11). The mean Charlson index score was 3.0 (2.5), with estimated 10 -year survival of $60-70 \%$.

Mortality in our group, like that described in the literature, was $5 \%$. Chronic obstructive pulmonary disease is the fourth leading cause of death, and it is expected to reach close to third place in the year 2020. This is also a leading cause for repeated admissions in the United States of America, especially in adults. Patients who require IMV have higher mortality rates; various studies demonstrated that mortality rate ranged from $2.5 \%$ to $30 \%(18,20,21)$. In our IMV group, mortality rate was close to $15 \%$.

There are two leading reasons for the mortality in our sample - sepsis and COPD at an advanced stage. Involvement of other systems and the number of days of hospitalization before the IMV, older age, and recurrent hospitalizations, physiological variables such as hypoxia and hypercarbia and co-morbidities were associated with higher mortality rates. In our study, the age of the patients who died was higher than 75 years old, when $95 \%$ of patients were over 65 years $(p<0.001),(11,18,19,21)$ [Table 3].

In addition to the failure of weaning from the IMV, the need for recurrent ventilation and prolonged hospitalization were all factors that determined the high percentage of mortality during hospitalization. Prolonged hospitalizations cause failure in the weaning process, and prolonged ventilation hold higher risk of developing pneumonia, the socalled ventilation-associated pneumonia (VAP), resulting in a rise in mortality $(20,21,23)$.

Co-morbidities, which we found in our patients, were hypertension, diabetes, ischaemic heart disease and heart failure. Similar numbers were presented recently in articles that analyse the mortality in patients with $\operatorname{COPD}(24,25)$. Other factors associated with worsening of the disease are continued smoking, ischaemic heart disease and malignancy; they are more common in this group of disease. Some studies showed other diseases like chronic renal failure, pulmonary hypertension, right heart failure also with high percentage of mortality especially those with prolonged IMV $(14,18,20,23,26)$.

\section{CONCLUSION}

Any flare or COPD exacerbation may need hospitalization and in some patients, IMV. Most patients in the medical department needed about five days of hospital stay and the patient with IMV significantly increases the duration of the hospital stay in ICU. In this study, we reviewed the outcome of patients with AECOPD, hospital stay in internal medicine departments, the need for IMV, complications and mortality, the differences between the internal medicine department and intensive care unit. 
The results showed better outcome to that described in the literature in terms of average days of hospitalization and mortality in both departments. In addition, this study is unique in showing the difference between ICU and Internal Medicine Department. The study also supports the fact that the need for prolonged mechanical ventilation is predictive of bad prognosis, and clinicians must make all efforts to ensure that patients will benefit from non-invasive ventilation in the general medical wards.

\section{Authors' note}

The authors declare that they have no competing interests.

\section{REFERENCES}

1. Calverley PM, Walker P. Chronic obstructive pulmonary disease. Lancet 2003; 362: 1053-61.

2. De Groot V, Beckerman H, Lankhorst GJ, Bouter LM. How to measure comorbidity: a critical review of available methods. J Clin Epidemiol 2003; 56: 221 .

3. Barnes PJ. Chronic obstructive pulmonary disease. N Eng J Med 2000; 343: $269-80$.

4. Anto JM, Vermeire P, Vestbo J, Sunyer J. Epidemiology of chronic obstructive pulmonary disease. Eur Respir J 2001; 17: 982-94.

5. Pauwels RA, Buist AS, Calverley PM, Jenkins CR, Hurd SS. Global strategy for the diagnosis, management, and prevention of chronic obstructive pulmonary disease. NHLBI/WHO Global Initiative for Chronic Obstructive Lung Disease (GOLD) Workshop summary. Am J Respir Crit Care Med 2001; 163: 1256-76.

6. Decramer M, Janssens W, Miravitlles M. Chronic obstructive pulmonary disease. Lancet 2012; 379: 1341-51. doi: 10.1016/S01406736(11)60968-9.

7. de Miguel-Díez J, Jiménez-García R, Hernández-Barrera V, PuenteMaestu L, Rodríguez-Rodríguez P, López de Andrés A et al. Trends in hospital admissions for acute exacerbation of COPD in Spain from 2006 to 2010. Respir Med 2013; 107: 717-23. doi: 10.1016/j.rmed. 2013.01.007. Epub 2013 Feb 17.

8. Varsano S, Jacoby I, Garenkin M. [Proper use and the ability to teach the use of pressurized hand-held inhalers in patients with chronic airway obstruction]. Harefuah 1999; 136: 9-14, 96.

9. Finkelstein R, Fraser RS, Ghezzo H, Cosio MG. Alveolar inflammation and its relation to emphysema in smokers. Am J Respir Crit Care Med 1995; 152: 1666-72.

10. Saetta M, Di Stefano A, Turato G, Facchini FM, Corbino L, Mapp CE et al. CD8+ T-lymphocytes in peripheral airways of smokers with chronic obstructive pulmonary disease. Am J Respir Crit Care Med 1998; 157: 822-6.

11. Charlson ME, Pompei P, Ales KL, MacKenzie CR. A new method of classifying prognostic comorbidity in longitudinal studies: development and validation. J Chronic Dis 1987; 40: 373-83.
12. Farah R, Makhoul N. Optimal time needed for withdrawal mechanical ventilation in COPD patients. IMAJ 2011; 13: 609-2.

13. Vesbo J. Clinical assessment, staging, and epidemiology of obstructive pulmonary disease exacerbation. Am Thoracic Soc 2006; 3: 252-6.

14. Soo Hoo GW, Hakiman N, Santiago SM. Hypercapnic respiratory failure in COPD patients response to therapy. Chest 2000; 117: 169-77.

15. Holguin F, Folch E, Redd SC, Mannino DM. Comorbidity and mortality in COPD-related hospitalization in the United States, 1979 to 2001. Chest 2005; 128: 2005-11.

16. Kessler R, Faller M, Fourgaut G, Mennecier B, Weitzeinblum E. Predictive factors of hospitalization for acute exacerbation in a series of 64 patients with chronic obstructive pulmonary disease. Am J Respir Crit Care Med 1999; 159: 158-64.

17. Pauwels RA, Buist AS, Calverley PM, Jenkins CR, Hurd SS. Global strategy for diagnosis, management and prevention of chronic obstructive pulmonary disease. NHLBI/WHO Global Initiative for Chronic Obstructive Lung Disease (GOLD) Workshop summary. Am J Respir Crit Care Med 2001; 163: 1256-67.

18. Patil SP, Krishnan JA, Lechtzin N, Diette GB. In-hospital mortality following acute exacerbation of obstructive pulmonary disease. Arch Intern Med 2003; 163: 1180-6.

19. Nevins ML, Epstein SK. Predictors of outcome for patients with COPD requiring invasive mechanical ventilation. Chest 2001; 119: 1840-9.

20. Gunen H, Hacievliyagil SS, Kosar F, Mutlu LC, Gulbas G, Pehlivan E et al. Factors affecting survival of hospitalised patients. Eur Respir J 2005; 26: 234-41.

21. Ai-Ping CA, Lee KH, Lim TK. In-hospital and 5-year mortality of patient treated in the ICU for acute exacerbation of COPD: a retrospective study. Chest 2005; 128: 518-24.

22. Groenewegen KH, Schols AM, Wouters EF. Mortality and mortalityrelated factors after hospitalization for acute exacerbation of COPD. Chest 2003; 124: 459-67.

23. Quinnell TG, Pilsworth S, Shneerson JM, Smith IE. Prolonged invasive ventilation following acute ventilatory failure in COPD: weaning results, survival and the role of noninvasive ventilation; Chest 2006; 129: $133-9$

24. Nishimura K, Yasui M, Nishimura T, Oga T. Clinical pathway for acute exacerbations of chronic obstructive pulmonary disease: method development and five years of experience. Int J Chron Obstruct Pulmon Dis $2011 ; \mathbf{6}$ : $365-72$.

25. Pretto JJ, McDonald VM, Wark PA, Hensley MJ. Multicentre audit of inpatient management of acute exacerbations of chronic obstructive pulmonary disease: comparison with clinical guidelines. Intern Med J 2012; 42: 380-7.

26. Pincelli MP, Grumann AC, Fernandes C, Cavalheiro AG, Haussen DA, Maia IS. Characteristics of COPD patients admitted to the ICU of a referral hospital for respiratory diseases in Brazil. J Bras Pneumol 2011; 37: 217-22. English, Portuguese. 